No.4 p 31-38

\title{
The Educational Structure of the Population of Vojvodina
}

Plavša, J.*

\section{Abstract}

From the year 1953 to 1991 the population of Vojvodina increased in number at $18.5 \%$. However, the increase was different in each particular region in Vojvodina. Thus, the population increase in Bačka was 21.3\%, in Banat 5.1\% and in Srem $41.9 \%$ in the same period. Similar changes appeared in the educational structure of the analyzed groups of population: persons over 10 years of age (in 1953 there were 1.396.005 people belonging to this age group in Vojvodina i.e. $82.8 \%$ of the total population), and over 15 years of age (in 1991 there were 1.627.459 people belonging to this age group in Vojvodina, i.e. $80.8 \%$ of the total population). During this period the portion of the illiterate decreased at $8.6 \%$, i.e. almost three times (by 109.299 persons). The majority of these were women (in $195369.6 \%$ of the illiterate were women, and in 1991 as many as 75.4\%). From the year 1953 to 1991 the portion ofpeoplewithout primaryschool education decreased at $21.7 \%$, i.e. 4.2 times (by 286.836 persons). It should be noticed that in 1991 there were as many as 432.679 persons (26.6\%) who had not completed primary school. The portion of those who completed primary school decreased from 56.3\% in 1953 to $25.3 \%$ in 1991 , whereas the portion ofthosewhocompletedsecondaryschool increased from $14.0 \%$ to $33.0 \%$ (2.4

times). However, the major change took place in the group of population who acquired college or university degrees. In the year 1953 the portion of this group represented $0.5 \%$ of theanalyzed population whereas in 1991 it was 7.4\%, which means that the portion of this category increased 14.8 times.

Key words: educational structure of the population, Vojvodina

* JovanPlavša,InstituteofGeography,University of Novi Sad, YU, Novi Sad ,Trg Dositeja Obradovića 3 or the purpose of fast and successful development of towns, regions and countries the educational level of population is the matter of utmost importance. Monitoring the educational structure of the population enables timely, relatively simple planned and successfully conducted activities by which to influence the development of the total population in a particular area.

Following the World War II, Yugoslavia and Vojvodina underwent a relatively fast development, although this process was not evenly distributed in the whole area. Thus, in the analyzed period significant differences were recorded between the regions of Bačka, Banat and Srem. The total rate of development was not always followed by the adequate education, and more often than not, no adequate measures were taken to co-ordinate the economic development with the educational system. Besides, certain categories of educational structure have been under the negative influence of constant emigration, especially of university educated population, as Vojvodina also faces the problem of the so called "brain drain". From 1953 to 1991 there were several changes in the educational system which affected all educational categories. Moreover, the systematics of censuses and statistical data processing underwent changes. However, with slight corrections, it is possible to analyze and compare the data.

\section{Literacy analysis}

In the analyzed groups of population of Vojvodina and its regions both in the mid and late 20th century there more women than men. Still these differences were not too big, and they can be said to have been within the limits of the general population trends. Partly, they are also the consequence of the war. In the year 1953 the percentage of female population in Bačka and Srem was higher than the average in Vojvodina (52.5\%), whereas in Banat it was lower at nearly one per cent. In the early 90's the percentage of female population over 10 years of age was $51.9 \%$, and it was slightly higher only in Bačka.

In the group of literate population these differences are smaller. In 1953 the percentage of literate male and female population is equal in the whole of Vojvodina (in absolute terms, the number of men is higher by several dozens). In Bačka and Srem the number of literate female population is higher at approximately $1 \%$, whereas in Banat the number of male literate population is higher at $2.5 \%$. It should also be mentioned here that the portion of the literate people over 10 years of age in Vojvodina $(87.0 \%)$ was at the same level as in the most developed countries. The percentage of the literate in Bačka was at $1.4 \%$ higher than the average in Vojvodina, whereas in Srem and Banat it was lower than the average at $0.1 \%$ and $1.7 \%$ respectively. By the year 1991, in addition to the absolute increase in the literate population, the percentage of literate female population also rose, which means that the education of males and females had been equaled. The portion of the literate in 1991 Vojvodina population $(95.6 \%)$ is large, but at a slight percentage lower than that of the most developed countries (97-99\%) and that of the former Warsaw Pact countries. The lower level of literacy in Vojvodina in comparison with the countries mentioned was due to the immigration of a great number of illiterate population. Again, compared to the average in Vojvodina the level of literacy was higher in Bačka, and lower in Srem and Banat.

In the second half of the $20^{\text {th }}$ century the number of the illiterate in Vojvodina dropped dramatically. In 1953 the number of the illiterate in Vojvodina (181.217 persons, i.e. $13.0 \%$ ) made up slightly over one eighth of the total population, whereas in the whole of Serbia the number of the illiterate (1.558.773 persons, i.e. $27.9 \%)$ made up between one third and one quarter of the total population. Regardless of the natural and social uniformity of Vojvodina, there were still differences between Bačka, Banat and Srem. The highest percentage of the illiterate was in Banat (14.8\%), which was almost $2 \%$ higher than Vojvodina average. This is the result of the fact that this region is more peripheral, and has a higher percentage of agricultural population, but also of the fact that after the World War II it was inhabited by the 
greatest number of immigrants from the undeveloped parts of the countryamong whom there were a large number of illiterate persons. At the time Srem had $13.1 \%$ of the illiterate, and Bačka $11.7 \%$, although in absolute terms the highest number of the illiterate was in Bačka, which is logical considering its higher number of population. The illiterate of Backa make up $44.0 \%$ of the total number of the illiterate in Vojvodina in 1953, which is at $4.6 \%$ lower than percentage of Bačka population over 10 years of age within the same age group of Vojvodina. The portion of the illiterate from Banat makes up $41.1 \%$, and that from Srem $14.9 \%$ of the same group in Vojvodina.

The analysis conducted in smaller districts of Vojvodina showed considerable diversity and proved that the number of the illiterate in 1953 was the greatest in the areas inhabited by the immigrants from the undeveloped parts of the country after the World War II. In the year 1953 the district which is at present covered by Sečanj municipality had $20 \%$ of the illiterate. The situation was similar in Kovin area, and the area surrounding Bačka Palanka had over $18 \%$ of the illiterate. The areas which are at present covered by the municipalities of Odžaci, Bač, Žitište, Nova Crnja, Bela Crkva and Kikinda had between $17 \%$ and $18 \%$ of the illiterate.

However, the total population of certain towns had $50 \%$ or more of the illiterate (Karavukovo 53.6\%, Maglić $51 \%$, Novi Kozarci 50.9\%, Kočićevo $50.7 \%$, Čestereg 50.4\%, Mladenovo $50 \%$, Banatsko Veliko Selo 49.2\%, Žarkovac 48.3\%, Ljukovo 47.9\%, Nakovo 47.2\%, Lukićevo $45.9 \%$ and Bački Jarak $45.5 \%)$. The lowest percentage of the illiterate people over 10 years of age in 1953 was in the districts where the majority of population were ethnic mi- norities (Senta 6.5\%, Bečej 9.7\%, Novi Kneževac 10.7\%) and in cities (Novi Sad $4.7 \%$, Zrenjanin $7.5 \%)$. It should also be mentioned that the whole part of Mačva which became part of Srem had more than $30 \%$ of the illiterate in the population over 10 years of age.

Throughout the analyzed period the percentage of illiterate women in the population over 10 years of age was considerably higher. In 1953 women represented more than two thirds of the total of the illiterate. The percentage of illiterate women in Bačka (70.3\%) was slightly higher than the average in Vojvodina (69.6\%), whereas in Banat it coincided with the average (69.5\%), and in Srem it was at nearly $2 \%$ lower than the average $(67.7 \%)$. The comparison of the percentage of male and female illiterate population within their own sex groups gives interesting results. The illiterate men make up slightly less than Table1.ThepopulationofVojvodina,Bačka,BanatandSremover10yearsofageanalyzed bythecriteriaofeducationallevelandliteracy in the year 1953.

\begin{tabular}{|c|c|c|c|c|c|c|c|c|c|}
\hline & Total & Literate & Illiterate & $\begin{array}{c}\text { Without } \\
\text { education }\end{array}$ & $\begin{array}{l}\text { Primary } \\
\text { school } \\
\end{array}$ & $\begin{array}{c}\text { Low Secondary } \\
\text { school }\end{array}$ & $\begin{array}{c}\text { Secondary } \\
\text { school }\end{array}$ & $\begin{array}{l}\text { High School } \\
\text { and College } \\
\end{array}$ & Unknown \\
\hline \multicolumn{10}{|l|}{ Vojvodina } \\
\hline Total & 1396005 & 1214788 & 181217 & 398936 & 785296 & 162531 & 33467 & 6988 & 8787 \\
\hline \%off total & 100.00 & 87.02 & 12.98 & 28.58 & 56.25 & 11.64 & 2.40 & 0.50 & 0.63 \\
\hline Male & 662678 & 607557 & 55121 & 150827 & 375306 & 105842 & 20113 & 5471 & 3815 \\
\hline$\%$ & 47.47 & 50.01 & 30.42 & 37.80 & 47.79 & 65.12 & 60.10 & 78.29 & 43.42 \\
\hline Female & 733327 & 607231 & 126096 & 248109 & 409990 & 56689 & 13354 & 1517 & 4972 \\
\hline$\%$ & 52.53 & 49.99 & 69.58 & 62.20 & 52.21 & 34.88 & 39.90 & 21.71 & 56.58 \\
\hline \multicolumn{10}{|l|}{ Bačka } \\
\hline Total & 684090 & 604391 & 79699 & 193070 & 372435 & 92504 & 18112 & 4148 & 3821 \\
\hline \%off total & 100.00 & 88.35 & 11.65 & 28.22 & 54.44 & 13.52 & 2.65 & 0.61 & 0.56 \\
\hline Male & 322535 & 298894 & 23641 & 72883 & 174610 & 59649 & 10814 & 3230 & 1641 \\
\hline$\%$ & 47.15 & 49.45 & 29.66 & 37.75 & 46.88 & 64.48 & 59.71 & 77.87 & 42.95 \\
\hline Female & 361555 & 305497 & 56058 & 120187 & 197825 & 32855 & 7298 & 918 & 2180 \\
\hline$\%$ & 52.85 & 50.55 & 70.34 & 62.25 & 53.12 & 35.52 & 40.29 & 22.13 & 57.05 \\
\hline \multicolumn{10}{|l|}{ Banat } \\
\hline Total & 505488 & 430945 & 74543 & 151613 & 285751 & 50757 & 11540 & 2069 & 3758 \\
\hline \%off total & 100.00 & 85.25 & 14.75 & 29.99 & 56.53 & 10.04 & 2.28 & 0.41 & 0.74 \\
\hline Male & 243556 & 220767 & 22755 & 58011 & 142447 & 32777 & 7012 & 1633 & 1676 \\
\hline$\%$ & 48.18 & 51.23 & 30.53 & 38.26 & 49.85 & 64.58 & 60.76 & 78.93 & 44.60 \\
\hline Female & 261932 & 210178 & 51784 & 93602 & 143304 & 17980 & 4528 & 436 & 2082 \\
\hline$\%$ & 51.82 & 48.77 & 69.47 & 61.74 & 50.51 & 35.42 & 39.24 & 21.07 & 55.40 \\
\hline \multicolumn{10}{|l|}{ Srem } \\
\hline Total & 206427 & 179452 & 26975 & 54253 & 127110 & 19270 & 3815 & 771 & 1208 \\
\hline \%off total & 100.00 & 86.93 & 13.08 & 26.28 & 61.58 & 9.34 & 1.85 & 0.37 & 0.59 \\
\hline Male & 96587 & 87896 & 8725 & 19933 & 58249 & 13416 & 2287 & 608 & 498 \\
\hline$\%$ & 46.79 & 48.98 & 32.34 & 36.64 & 45.83 & 69.62 & 59.95 & 78.86 & 41.23 \\
\hline Female & 109840 & 91556 & 18250 & 34320 & 68861 & 5854 & 1528 & 163 & 710 \\
\hline$\%$ & 53.21 & 51.02 & 67.66 & 63.26 & 54.17 & 30.38 & 40.05 & 21.14 & 58.77 \\
\hline
\end{tabular}

Source: 1953 Census, Federal Bureau of Statistics in Belgrade 

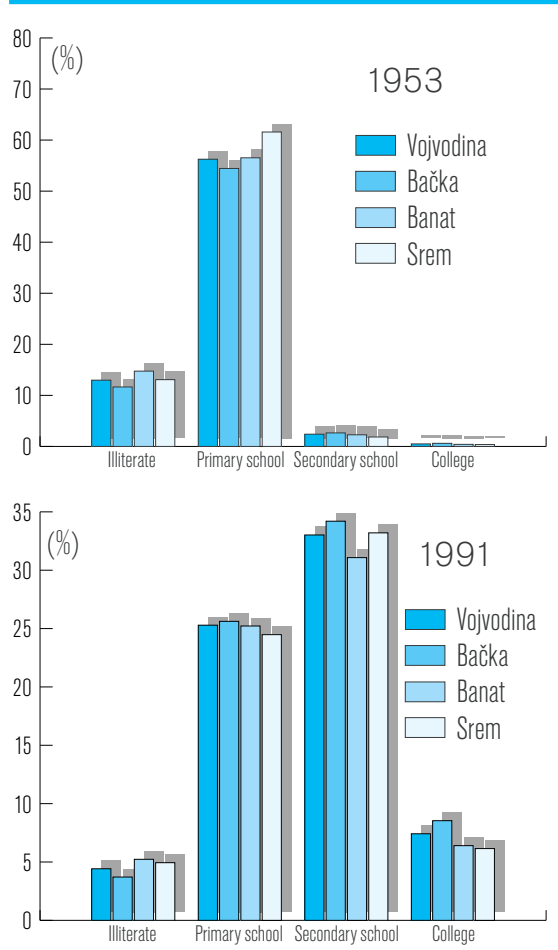

Figure 1. Bar chart of the percentage of the illiterate, persons with primary and secondary school, college and university degreesinVojvodina,Bačka,BanatandSrem in 1953 and 1991.

one tenth of their sex group over 10 years of age (Vojvodina 8.3\%, Bačka 7.3\%, Banat 9.3\%, Srem 9.0\%). Within the female group over 10 years of age the percentage of the illiterate is twice as high (Vojvodina 17.2\%, Bačka 15.5\%, Banat 19.8\%, Srem 16.6\%).

From 1953 to 1991 the total population in the analyzed group increased by 231.454 persons, and the number of the illiterate decreased by 109.299 persons, i.e. 2.5 times. The percentage of the illiterate in Vojvodina (4.4\%) is almost three times (2.9) lower. Even now at the very end of the $20^{\text {th }}$ century the lowest percentage of the illiterate is in Bačka (3.7\%, i.e. 3.1 times less than in 1953), whereas in Banat $(5.2 \%$, i.e. 2.8 times less), and in Srem (4.9\%, i.e. 2.6 times less) it is higher than the average in Vojvodina. Although the general level of literacy and education has improved to a large extent, this fact is mostly true of the male population. The percentage of illiterate men over 10 years of age in their own sex group exceeds $2 \%$ only in Banat (Vojvodina 2.0\%, Bačka 1.7\%, Banat $2.5 \%$, Srem 1.9\%), so that it has dropped to the level of the most developed countries. The percentage of illiterate women (5.6\%) in the whole of Vojvodina is almost three times higher than that of the male population. In Bačka it is 3.3 times higher (5.6\%), in Srem 4.1 times (7.8\%) and in Banat 3.1 times.

The highest percentage of the illit- erate is still mainly in the areas which were populated following the World War II according to a plan. Over $8 \%$ of the illiterate were recorded in the municipalities of Odžaci (8.6\%), Bač $(8.4 \%)$, Sečanj (8.4\%) and Kovin (8.1\%). Still, this percentage is over two times lower than in 1953. There are still 17 other municipalities with over $5 \%$ of the illiterate, which together with the four mentioned above, makes up almost half of all Vojvodina municipalities (46.7\%). Apart from Odžaci and Bač, the following municipalities in Bačka had over $5 \%$ of the illiterate in the year 1991: Žabalj (7.9\%), Titel (6.4\%), Bačka Palanka (5.8\%) and Apatin (5.01\%). As for Banat, apart from Sečanj and Kovin the situation is similar in the following municipalities: Nova Crnja (7.7\%), Žitište (7.5\%), Opovo (6.4\%), Kikinda (5.9\%), Plandište (5.7\%), Bela Crkva (5.3\%), Pančevo (5.2\%) and Novi Bečej (5.1\%). In Srem more than $5 \%$ of the illiterate were registered in the municipalities of Ruma (6.4\%), Šid (5.3\%), Inđija (5.3\%) and Pećinci (5.25\%).

The lowest percentage of the illiterate was mainly recorded in the municipalities where the majority of population is made up of ethnic minorities. In the municipality of Kanjiža the percentage of the illiterate is below $2 \%(1.96 \%)$, whereas the folowing municipalities have slightly higer percentage: Subotica (2.1\%), Ada (2.2\%), Senta (2.6\%), Mali Iđoš (3.02\%), Bečej (3.2\%), Čoka (3.3\%), Bački Petrovac (3.3\%) and Bačka Topola (3.5\%). The municipality of Novi Sad (the capital of the Province) also belongs to this group with $2.2 \%$, so does Sremski Karlovci (2.6\%), the town with a very old cultural tradition, which alone represents a small municipality. The percentage of the illiterate is below $4 \%$ in the municipalities of Stara Pazova (3.7\%) and Zrenjanin (3.7\%).

As for cities, the lowest percentage of the illiteraate in Bačka was recorded in Kanjiža (1.08\%), then Bački Petrovac (1.10\%), Novi Sad (1.18\%), Ada (1.23\%), Bačka Topola (1.54\%), Subotica (1.55\%) etc, whereas the highest percentage of the illiterate was Bač (8.16\%), Žabalj (7.84\%), Odžaci $(4.96 \%)$, Titel $(4.56 \%)$ and Bačka Palanka (4.00\%). There are two villages in Bačka with the percentage of the illiterate below 1\%: Doline in the municipality of Kanjiža (0.94\%) and Gložan in the municipality of Bački Petrovac (0.96\%). The highest percentage of the illiterate in Bačka (16.13\%) was recorded in the village of Mladenovo (the municipality of Bačka Palanka), followed by Karavukovo (14.63\%) and Maglić (13.79\%). The highest per- centage of the illiterate women was recorded in the following municipalities: Odžaci (83.6\%), Mali Iđoš (83.2\%) and Vrbas (83.1\%). The lowest percentage of the illiterate women was recorded in Senta (59.6\%), Ada (65.2\%) and Kanjiža $(65.7 \%)$. In the village of Doline, there are no illiterate women. In Bačka there are eight villages in which the illiterate women make up $50 \%$ of all the illiterate (the municipalities of Ada, Senta and Kanjiža). Also, there are several other villages in which the illiterate women make up over 90\% (Nova Gajdobra 95.7\%, Gornja Rogatica 95.0\%, Bački Sokolac 92.6\%, Mišićevo 90.9\% and Lovćenac 90.6\%).

Among the cities of Banat the lowest percentage of the illiterate was recorded in Kovačica (1.00\%), then Coka $(1.86 \%)$, Novi Kneževac (2.10\%), Zrenjanin (2.14\%) and Pančevo (2.34\%). The highest percentage was recorded in Jaša Tomić (11.34\%), Žitište (8.55\%), Kovin (6.23\%) and Opovo (4.72\%). The village of Banatski Monoštor (the municipality of Čoka) has no illiterate inhabitants over 15 years of age, whereas in Vojvodinci (the municipality of Vršac) the percentage of the illiterate is $0.59 \%$, in the village of Rabe (municipality of Novi Kneževac) $0.60 \%$, in Sočica (municipality of Vršac) $0.80 \%$ and in Padina (Kovačica municipality) $0.89 \%$. The village of Malo Bavanište (Kovin municipality) has the highest percentage of the illiterate in Vojvodina (18.18\%), whereas a slightly lower percentage of this category was recorded in Putnikovo (17.04\% Kovačica municipality). In approximately 20 villages of Banat the percentage of the illiterate is between $10 \%$ and $14 \%$. In municipalities in Banat women make up between $70 \%$ and $80 \%$ of all the illiterate. This percentage is the lowest in the municipalities of Bela Crkva (71.4\%), Novi Kneževac (72.1\%) and Kovačica (72.99\%). The highest percentage was recorded in the municipalities of Sečanj (79.1\%), Zrenjanin (78.9\%) and Plandište (78.5\%). Apart from Banatski Monoštor the villages of Rabe and Češko Selo (Bela Crkva municipality) do not have any illiterate women, whereas in u Vojvodinci women make up 33.3\% and in Kajtasovo (Bela Crkva municipality) $55.0 \%$. In the villages of Vršački Ritovi, Busenje (Sečanj municipality), Sočica and Banatsko Višnjićevo (Žitište municipality) all the illiterate (100\%) are women.

Among the cities of Srem the lowest percentage of the illiterate was recorded in Stara Pazova (2.5\%), Sremski Karlovci (2.6\%) and Sremska Mitrovica (2.98\%), whereas the highest percent- 
age was recorded in Beočin (5.0\%), Inđija (4.8\%), Ruma (4.5\%) and Irig (4.0\%). The only village with the percentage of the illiterate below $1 \%$ is Lug $(0.77 \%)$ in the municipality of Beočin. The following villages have the highest percentage of the illiterate: Jarkovci (13.9\% - Inđija municipality), Vitojevci (13.8\%) and Putinci (13.1\%) in the municipality of Ruma. The percentage of women among the illiterate was recorded in the municipality of Inđija (87.8\%), whereas the only municipality where this percentage is below $80 \%$ is Šid (78.95\%). In the village of Velika Remeta (Irig municipality) there are no women among the illiterate, whereas in the village of Bešenovački Prnjavor (Sremska Mitrovica municipality) $50 \%$ of the illiterate are women, and in Lug this percentage is $60 \%$. The majority of towns in Srem have between $75 \%$ and $85 \%$ of women among the illiterate, whereas there are five villages where all the illiterate persons are women (Stara Bingula, Grgeteg, Sviloš, Krušedolski Prnjavor and Bikić Do). It should be added here that in the cases of noticeably low percentage illiteracy both among men and women or where the illiterate are not recorded at all, the villages in questions generally have very small number of inhabitants.

Apart from the significant decrease in the number of the illiterate in the second half of the $20^{\text {th }}$ century, it is important to mention that the majority of the illiterate (around $80 \%$ ) are over 60 years of age, and these persons are mainly retired. Considering the factor of mortality, it is to be expected that the number of the illiterate will further be decreasing within the years to come.

\section{The analysis of the educational structure of}

\section{population}

Educational background in one of the most important demographic factors of the overall development of a region. The disproportion of the educational structure of population and the economic functions of particular regions can lead to economic as well as social and political problems. In order to avoid this, it is important constantly co-ordinate the educational system and the economic, i.e. developmental needs. The following analysis aims to point to possible measures to be taken in order to improve the educational structure of the population.

Considering the fact that the illiterate persons make up the group of persons without any educational level, it is logical that the decrease in the illiterate results both in the decrease in the absolute number and percentage of the persons in the category "without education". One should notice that a considerable number of persons who attended primary school for some time never completed it. In the year 1953 the percentage of persons "without education" in Vojvodina (28.6\%) was 2.2 times higher than the percentage of the illiterate. The situation was similar in all Vojvodina's regions. The percentage of this category among persons over 15 years of age in Banat was 30\%, in Bačka it was lower at nearly $2 \%$ (28.2\%), which is slightly below the average in Vojvodina. The average in Srem was at 2.3\% lower than the average in Vojvodina. By the final decade of the $20^{\text {th }}$ century the percentage of this category in Vojvodina decreased at $21.7 \%$, which means that in the year 1991 it was 4.1 times lower than in 1953. According to the 1991 census there were only $2-3 \%$ of persons more in this category than the illiterate. This means that nowadays there are far fewer persons who attended school and have not completed it. The highest percentage of the group "without education" is in Srem (8.0\%), then in Banat (7.8\%), whereas in Bačka it is approximately at $2 \%$ lower (i.e. at $1 \%$ below the average of Vojvodina).

It should be mentioned that primary school education underwent major changes in the period from 1953 to 1991 , especially in view of the length of compulsory education, as the compulsory period of four years at primary school was replaced with an eight year period. For this reason the 1991 census registered persons who completed four or six year primary school after the World War II in the category "incomplete primary school". The high percentage of persons with "incomplete primary school" (432.679 persons or $26.6 \%$ ) certainly represents a disadvantage, especially since the majority of this category are elderly persons unwilling to continue their education. This group together with the category "without education" make up one third (33.5\%) of the total population over 15 years of age in Vojvodina. This is a very high percentage and partly represents the hindrance to the development of the Province. Bačka has a lower percentage of these two categories at $2.6 \%$, whereas in Banat it is at $3.1 \%$ higher, and in Srem it is at 1.8\% lower than the average of Vojvodina. In both of these categories there is a considerably higher percentage of women. In the group "without education" the percentage of women was slightly over
$60 \%$ in 1953, and in 1991 it was over $70 \%$, i.e. more than two thirds of this category. In the year 1991women made up slightly less than two thirds (around $60 \%$ ) of the category "incomplete primary school". These relations point to the fact that less attention is paid to the education of females. The analysis of municipalities or towns shows the similar results to those of the illiterate, i.e. a higher percentage of persons "without education" and those with "incomplete primary school" in the municipalities inhabited by people from undeveloped parts of the former SFR of Yugoslavia after the World War II.

The highest percentage of the population in the category "without education" in Bačka in the year 1953 in the municipalities of Odžaci and Pačka Palanka (over 35\%), and the lowest was in Novi Sad municipality (18.9\%). The city of Novi Sad had only $13.3 \%$ of persons over 10 years of age in this category. Although in the year 1991 Bačka had the lowest percentage of persons "without education" on average, still some of the municipalities with the highest number of population in this categorybelong to this region. However, some municipalities in Bačka have not more $5 \%$ of population in this category. The highest percentage of this category was recorded in Odžaci (13.1\%), Žabalj (12.4\%), Bač $(11.7 \%)$ and Titel (10.9\%), whereas the lowest percentage was recorded in the municipalities of Novi Sad (3.8\%), Subotica (3.5\%), Ada (3.3\%), Senta (3.2\%) and Kanjiža (2.8\%). There four municipalities with slightly over $5 \%$ of population in this category (Bački Petrovac $5.1 \%$, Bačka Topola 5.1\%, Bečej 5.1\%, Mali Iđoš 5.2\%), and the other seven municipalities the percentage is between $7 \%$ and $10 \%$.

In the year 1953 the municipality of Sečanj had almost $40 \%$ (39.7\%) of population "without education", and the areas of Nova Crnja, Žitište and Kikinda had over $37 \%$. Almost twice lower percentage was recorded in the municipality of Pančevo (24.3\%), whereas the city of Zrenjanin had only $19.8 \%$ in this category. In the early 90's the following municipalities had over $10 \%$ of population "without education: Sečanj (12.1\%), Kovin (11.0\%), Nova Crnja (10.9\%) and Žitište (10.5\%). This means that in these municipalities this percentage decreased over three times. It was only in Kovačica that the percentage of this category was lower than 5\% (4.9\%); the municipalities of Čoka and Zrenjanin had less than $6 \%(5.2 \%$ and $5.9 \%$ respectively), and the other nine had between $6 \%$ and $10 \%$. 
The more uniform results in Srem (between 23\% and 30\% in 1953) are the consequence of a smaller number of administrative units there as well as the smaller number of immigrants after the World War II. In the year 1991 Srem had no municipalities where the percentage of the category "without education" is over $10 \%$. In Sremski Karlovci this percentage is $4.96 \%$. The highest percentage was recorded in the municipalities of Sremska Mitrovica (9.7\%) and Ruma (9.4\%), and there are six municipalities with $6 \%$ to $9 \%$ of population in this category.

According to the 1991 census 24 municipalities of Vojvodine (53.3\%) had over $30 \%$ of population in the category "incomplete primary school", whereas 18 municipalities (40.0\%) had between $20 \%$ and $30 \%$. Only 3 municipalities (6.7\%) had less than $20 \%$ of population in this group. As for Bačka the highest percentage was recorded in the municipalities of Kanjiža (38.0\%), Titel (35.7\%), Bač (35.6\%) and Srbobran (35.2\%), and the lowest was in Novi Sad (14.1\%), so that the highest difference is $23.9 \%$. In Banat two municipalities had over $40 \%$ (Čoka $41.4 \%$, Kovačica $40.6 \%$ ) of population in this group, and three municipalities had between 20\% and 30\% (Vršac 29.1\%, Kikinda 27.0\%, Zrenjanin 24.7\%). Only Pančevo municipality had below $20 \%$ of population in this group (19.3\%). In Bačka $45 \%$ or 9 municipalities had over $30 \%$ of population with incomplete primary school, in Banat 12 or $75 \%$, and in Srem $33.3 \%$ or 3 municipalities. Pećinci (37.3\%) and Irig (37.2\%) had the highest percentage of population $\mathrm{n}$ this group, and the lowest percentage was recorded in Sremski Karlovci (18.9\%).
The category of population with complete primary school education also underwent major changes. The percentage of this category in the educational structure of population has apparently decreased. At the same time there has been a significant increase in the population with high school as well as college and university education, which is a proof of great shift in a positive direction. After the World War II the percentage of persons with complete primary school education both in Vojvodina and its particular regions exceeded $50 \%$ (in Srem being as high as 60\%). In Bačka the highest percentage was recorded in Senta and Ada municipalities (over $60 \%)$, and the lowest in the municipality of Sombor $(52.5 \%)$. However, in certain cities it was below 50\% (Subotica 49.95\%, Novi Sad 46.3\%). In Banatu over $60 \%$ was recorded in the munici-

Table2. The population of Vojvodina, Bačka, Banat and Srem over 15 years of age according to the criteria of literacy and educational background in the year 1991.

\begin{tabular}{|c|c|c|c|c|c|c|c|c|c|}
\hline & Total & Literate & Illiterate & $\begin{array}{l}\text { Without } \\
\text { education }\end{array}$ & $\begin{array}{c}\text { Incomplete } \\
\text { primary school }\end{array}$ & $\begin{array}{c}\text { Primary } \\
\text { school }\end{array}$ & $\begin{array}{c}\text { Secondary } \\
\text { School }\end{array}$ & $\begin{array}{l}\text { High School } \\
\text { and College }\end{array}$ & Unknown \\
\hline \multicolumn{10}{|l|}{ Vojvodina } \\
\hline Total & 1627459 & 1555541 & 71918 & 112100 & 432679 & 411552 & 537333 & 120686 & 13109 \\
\hline \%off total & 100.00 & 95.58 & 4.42 & 6.89 & 26.59 & 25.29 & 33.02 & 7.42 & 0.81 \\
\hline Male & 782551 & 766978 & 15573 & 31383 & 170326 & 194226 & 312386 & 67549 & 6681 \\
\hline$\%$ & 48.08 & 49.31 & 21.65 & 28.00 & 39.37 & 47.19 & 58.14 & 55.97 & 50.96 \\
\hline Female & 844908 & 788563 & 56345 & 80717 & 262353 & 217326 & 224947 & 53137 & 6428 \\
\hline$\%$ & 51.92 & 50.69 & 78.35 & 72.00 & 60.63 & 52.81 & 41.86 & 44.03 & 49.04 \\
\hline \multicolumn{10}{|l|}{ Bačka } \\
\hline Total & 815181 & 784925 & 30256 & 48442 & 203605 & 208810 & 278822 & 69585 & 5937 \\
\hline \%off total & 100.00 & 96.25 & 3.71 & 5.94 & 24.98 & 25.62 & 34.20 & 8.54 & 0.73 \\
\hline Male & 389768 & 383216 & 6552 & 13705 & 77551 & 97154 & 159398 & 39035 & 2965 \\
\hline$\%$ & 47.81 & 48.82 & 21.66 & 28.30 & 38.07 & 46.53 & 57.17 & 56.10 & 49.94 \\
\hline Female & 425413 & 401709 & 23704 & 34717 & 126094 & 111656 & 119424 & 30550 & 2972 \\
\hline$\%$ & 52.19 & 51.18 & 78.34 & 71.70 & 61.93 & 53.47 & 42.83 & 43.90 & 50.06 \\
\hline \multicolumn{10}{|l|}{ Banat } \\
\hline Total & 525747 & 498229 & 27518 & 40771 & 151976 & 132603 & 163387 & 33667 & 3343 \\
\hline \%off total & 100.00 & 94.77 & 5.23 & 7.75 & 28.91 & 25.22 & 31.08 & 6.40 & 0.64 \\
\hline Male & 254355 & 247938 & 6417 & 11597 & 62106 & 63329 & 96818 & 18682 & 1670 \\
\hline$\%$ & 48.38 & 49.76 & 23.32 & 28.44 & 40.87 & 47.76 & 59.26 & 55.49 & 49.96 \\
\hline Female & 271392 & 250291 & 21201 & 29174 & 89870 & 69244 & 66569 & 14985 & 1673 \\
\hline$\%$ & 51.62 & 50.24 & 76.68 & 71.56 & 59.13 & 52.24 & 40.74 & 44.51 & 50.04 \\
\hline \multicolumn{10}{|l|}{ Srem } \\
\hline Total & 286531 & 272387 & 14144 & 22907 & 76896 & 70139 & 95126 & 17634 & 3829 \\
\hline \%off total & 100.00 & 95.06 & 4.94 & 7.99 & 26.84 & 24.48 & 33.20 & 6.15 & 1.34 \\
\hline Male & 138428 & 135824 & 2604 & 5928 & 30709 & 33743 & 56170 & 9832 & 2046 \\
\hline$\%$ & 48.31 & 49.86 & 18.41 & 25.88 & 39.94 & 48.11 & 59.05 & 55.76 & 53.43 \\
\hline Female & 148103 & 136563 & 11540 & 16979 & 46187 & 36396 & 38956 & 7802 & 1783 \\
\hline$\%$ & 51.69 & 50.14 & 81.59 & 74.12 & 60.06 & 51.89 & 40.95 & 44.24 & 46.57 \\
\hline
\end{tabular}

Source: 1991 Census, Federal Bureau of Statistics in Belgrade 


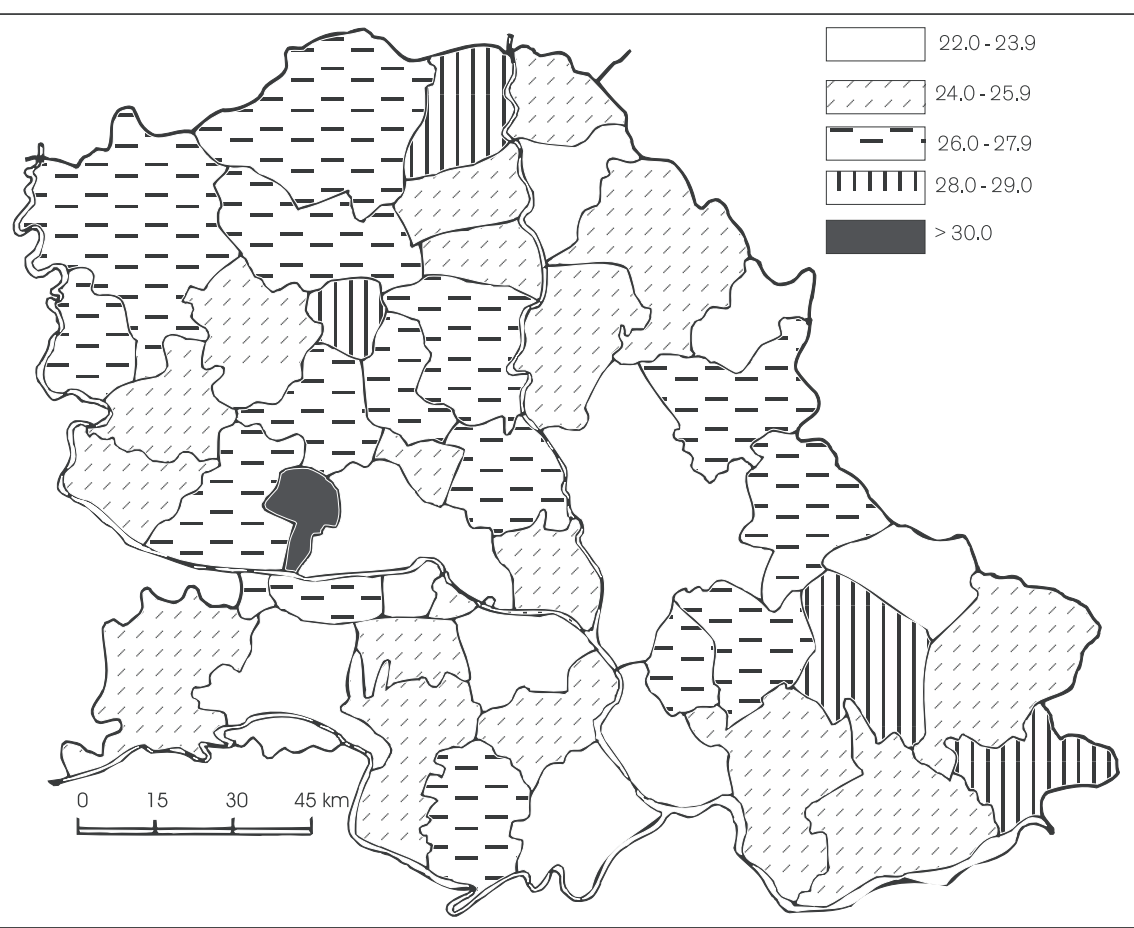

Figure2.Thepresentageofpopulationwithcompledetprimaryschoolinthemunicipalities of Vojvodina in 1991

palities of Alibunar (65.5\%) and Pančevo (60.5\%), and the lowest percentage was recorded in the municipality of Kikinda (48.5\%) and in the city of Zrenjanin (48.2\%). In Srem the percentage below $60 \%$ was recorded only in the municipality of Sremska Mitrovica (58.99\%). The percentage of this group at the end of this century has been reduced to one quarter of the population over 15 years of age, the differences between the regions and municipalities being negligible, which is logical in view of the fact that primary school education is compulsory. The highest percentage of population with primary school education in Bačka was recorded in the municipality of Bački Petrovac (31.1\%), and the lowest in that of Novi Sad (22.0\%). In half of the municipalities (10) there are over $27 \%$ of citizens with primary school education, but in the majority of municipalities (13 or $65 \%$ ) this percentage is between $25 \%$ and $27.5 \%$. In Banat it is highest in the municipalities of Bela Crkva (28.54\%) and Alibunar (28.51\%), whereas the lowest percentage was recorded in the municipality of Nova Crnja (22.9\%). Most municipalities (8 or $50 \%$ ) have between $25 \%$ and $27.5 \%$ of their population in this group. In Srem there are no municipalities with over $28 \%$ of population with primary school education. The highest percentage was recorded in Beočin (27.4\%), and the lowest in the municipality of Inđija (22.6\%). There are no significant differences between the sexes, i.e. both in 1953 and 1991 there was a slightly higher percentage of women within this group, which is to be expected, regarding the fact that there are more women in the total population.

A totally reverse, but at the same time an equally positive trend was recorded within the group of population who completed high school. From the year 1953 to 1991 the percentage of this group in Vojvodina increased 2.4 times (from $14.0 \%$ to $33.0 \%$ ). In Bačka the increase was 2.1 times (from 16.2\% to $34.2 \%$ ), in Banatu 2.5 times (from $12.3 \%$ to31.1\%), and in Srem 2.9 times (from $11.3 \%$ to $33.2 \%$ ). It is obvious that the percentage of this category in Bačka is above the average of Vojvodina both in 1953 and 1991, whereas in Banat it is lower than the average. In Srem this percentage was lower than the average of Vojvodina at nearly 3\% in the year 1953, but in 1991 it was at 0.2\% higher. Within this category, just as in that of population with college and university education, there is a higher portion of males, although these differences in the year 1991 were less pronounced than in 1953, which also points to the increasing equality in the education of the sexes. Within the category "high school education" four subgroups can be seen both in 1953 and 1991. In the year 1953 there was the highest percentage of persons who completed secondary school for general education both in Vojvodina as a whole and its particular regions (Vojvodina $6.5 \%$, Bačka $7.7 \%$, Banat 5.6\%, Srem $4.7 \%)$, then of those who completed lower professional school (Vojvodina $5.1 \%$, Bačka 5.8\%, Banat 4.5\%, Srem $4.6 \%)$, then high professional school
(Vojvodina 1.4\%, Bačka 1.6\%, Banat $1.3 \%$, Srem $0.99 \%$ ) and high school for general education - grammar school (Vojvodina 0.98\%, Bačka 1.04\%, Banat $0.96 \%$, Srem $0.86 \%$ ). It is interesting that women were more numerous only in the group "secondary school for general education" (lower grammar school). According to our results at the end of the $20^{\text {th }}$ century the relations between groups with different secondary of high school education are more uniform, with the exception of grammar schools, the percentage of which is considerably lower. The highest percentage is that of population with secondary school for special training (Vojvodina $11.0 \%$, Bačka $10.8 \%$, Banat $10.3 \%$, Srem $13.0 \%)$; similar to this is the percentage of the category "schools for skilled workers and professional training" (Vojvodina $10.4 \%$, Bačka $10.7 \%$, Banat $10.7 \%$, Srem 9.1\%) and "secondary schools for professional training" (Vojvodina 9.3\%, Bačka 10.2\%, Banat 8.0\%, Srem 9.2\%). The percentage of the group of population with grammar school education in Vojvodina was $2.3 \%$. The percentage in Bačka is slightly higher than the average of Vojvodina (2.5\%), whereas in Banat and Srem it is slightly lower than the average $(2.1 \%$ and $1.9 \%$ respectively). According to the 1991 census the percentage of women was higher only in the category of grammar schools. However, as in the category of college and university education men make up a higher percentage, it can be concluded that a high portion of females with completed grammar schools do not enroll in colleges or universities. Still, this difference was considerably smaller than in 1953.

The percentage of population (1953) who completed high school varied through different administrative units. In the year 1953 in Bačka the highest percentage of this group was recorded in Novi Sad municipality (24.5\%), and the lowest in Odžaci municipality (8.8\%). In the city of Subotica there were $19.2 \%$ of persons in this group, whereas in the city of Novi Sad there were $37.6 \%$. In Banat the highest percentage was recorded in the municipalities of Vršac (13.7\%) and Kikinda (13.3\%), and the lowest in Alibunar municipality (6.0\%). The city of Zrenjanin had $30.4 \%$ of population in this category. In Srem the differences were smaller, so the highest percentage was recorded in the municipality of Sremska Mitrovica (13.7\%), and the lowest in the area of Ruma and Pećinci (9.6\%). In the year 1991 there were 12 municipalities in Bačka (60\%) with over $30 \%$ of population with com- 
pleted high school. It should be mentioned that the municipality of Novi Sad had $43.0 \%$ of population in this category. The percentage below $25 \%$ was recorded in the municipalities of Titel (24.9\%) and Bač (23.7\%). In Banat there were only 4 municipalities (25\%) with the percentage of this category over $30 \%$ (Pančevo 38.1\%, Zrenjanin 37.2\%, Kikinda $32.6 \%$ and Vršac 31.3\%), and there were 3 municipalities where the percentage was below 22\% (Nova Crnja 21.9\%, Žitište $21.3 \%$ and Alibunar 21.3\%). In Srem, the highest percentage was recorded in Sremski Karlovci (41.6\%), and in the total of 6 municipalities (66.7\%) this percentage exceeds $30 \%$. The lowest percentage was recorded in the municipality of Pećinci (24.5\%). The analysis of the category of population with completed grammar school, which is the basis for further college or university education, leads to similar results. The municipality of Sremski Karlovci has over $5 \%(5.3 \%)$, and that of Novi Sad $4.4 \%$. As for the other municipalities, the percentage of above $3 \%$ is found in Bački Petrovac (3.4\%). In Bačka there are 7 more municipalities (35\%) where the percentage of this category is between $2 \%$ and $3 \%$. In the other 11 municipalities (55\%) this percentage is between $1 \%$ and $2 \%$. In Banat there are 4 municipalities (25\%) with over $2 \%$ of population in this category - the highest percentage being in Zrenjanin (2.8\%), whereas 10 municipalities (62.5\%) have between $1 \%$ and $2 \%$, and 2 below $1 \%$ of population in this group (Alibunar $0.98 \%$, Opovo $0.80 \%$ ).

It has already been mentioned that the most intensive and the most significant changes took place in the group of population with college and university education. In the year 1953 the percentage of this category in Vojvodina and its regions was below $1 \%$. The average of Vojvodina $(0.50 \%)$ was exceeded in Bačka (0.61\%), whereas in Banat and Srem it was lower $(0.41 \%$ and $0.37 \%$ respectively). Within this group there were $22.1 \%$ of women in Bačka, and $21.1 \%$ in Banat and Srem. By the year 1991 the percentage of population with college and university education in Vojvodina increased 14.8 times. In Bačka this increase was 14 times, in Banat 15.6 and in Srem 16.6 times. The percentage of women within the group has also increased so that it has reached $44 \%$. The comparison of college on the one and university education on the other hand shows that percentage of each is approximately the same in the year 1991. In contrast, the analysis of the same data from the year 1953 shows that the per-

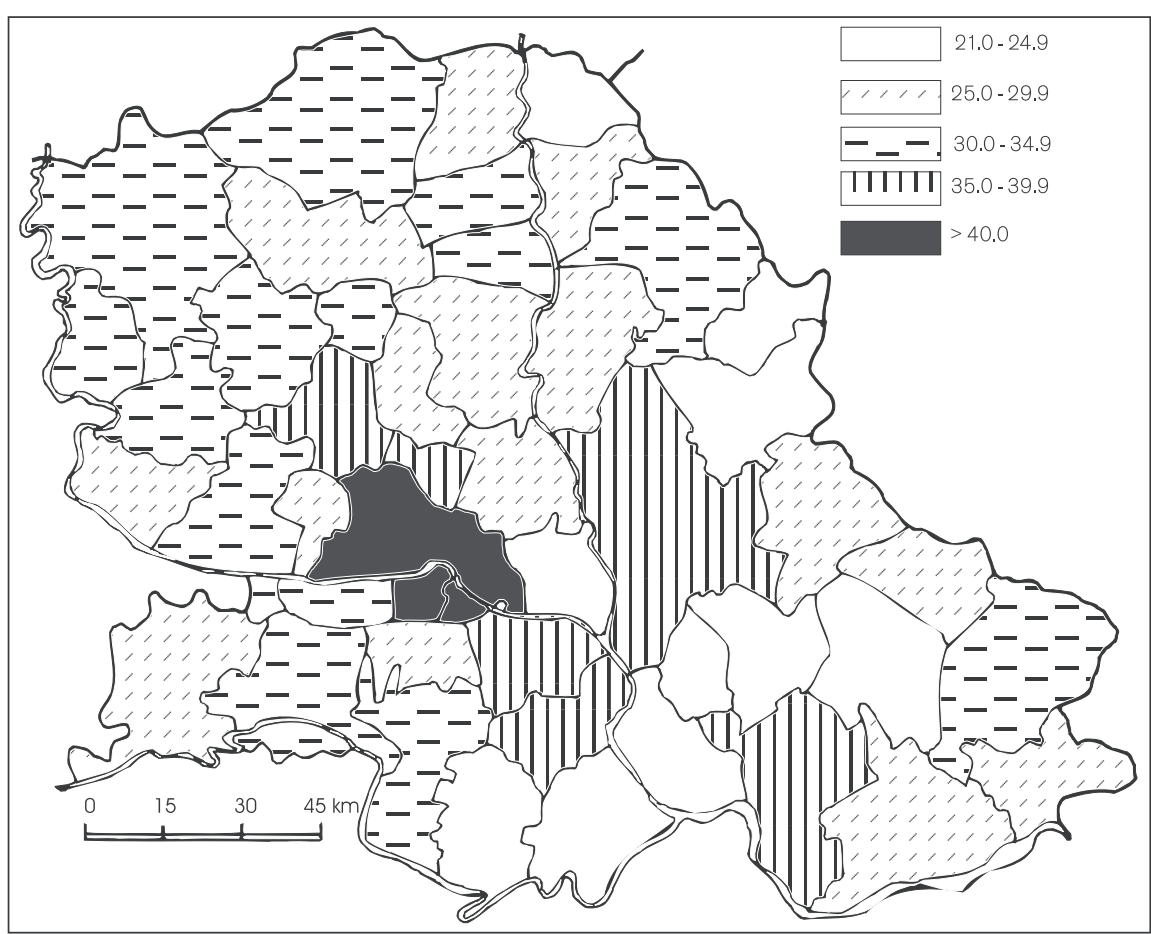

Figure4.Thepercentageofpopulationwithcompletedhighschoolinthemunicipalities of Vojvodina in 1991

centage of persons with college education was considerably higher. In the year 1991 the average of Vojvodina was $3.94 \%$ of persons with university education and $3.49 \%$ of those with college education. The percentage was higher in Bačka (university education $4.80 \%$, college education $3.73 \%$ ) and lower in Banat (university education 3.09\%, college education 3.31\%) and Srem (university education $3.01 \%$, college education 3.14\%).

In Bačka it was only in the municipality of Novi Sad in the year 1991 that the percentage of the category with college education exceeded 5\% (5.8\%). There were 6 municipalities (30\%) where this percentage was between $3 \%$ and $4 \%$ (Subotica 3.8\%, Senta 3.6\%, Sombor $3.3 \%$, Vrbas 3.3\%, Kula 3.1\%, Ada 3.0\%). There were 11 municipalities (55\%) where the percentage was between $2 \%$ and $3 \%$, and $2(10 \%)$ where it was below 2\% (Srbobran 1.9\%, Žabalj 1.9\%). As for Banat, there were 2 municipalities (12.5\%) where the percentage of this category was over $4 \%$ (Zrenjanin $4.2 \%$ and Pančevo $4.0 \%$ ), and 2 with the percentage between $3 \%$ and 4\% (Vršac 3.8\% and Kikinda 3.6\%). In 11 municipalities (68.8\%) the percentage of this category was between $2 \%$ and 3\% (the highest in Sečanj municipality $2.6 \%$ and the lowest in Opovo municipality $2.0 \%$ ). In one municipality (6.3\%) this percentage was below $2 \%$ (Žitište 1.7\%). In Srem, the municipality of Sremski Karlovci had the highest percentage of this category (4.0\%). In 3 municipalities (33.3\%) this percentage is between 3\% and 4\% (Sremska Mitrovica 3.5\%, Ruma 3.2\%, Stara Pazova $3.1 \%)$, and in $4(44.4 \%)$ the percentage was between $2 \%$ and $3 \%$. There was only one municipality in Srem (11.1\%) where this percentage was below $2 \%$ (Pećinci 1.99\%). Similar results were found in the analysis of the category of population with university education. However, it should be stressed here that the percentage of this group was by far the highest in the municipality of Novi Sad (10.3\%) compared both to Bačka and Vojvodina average. In Backa, the next highest percentage was recorded in 5 municipalities (25\%), i.e. between $3 \%$ and 4\% (Subotica 3.95\%, Senta $3.60 \%$, Sombor $3.56 \%$, Vrbas $3.49 \%$, Bački Petrovac 3.08\%). There were 9 municipalities (45\%) with the percentage of this category between $2 \%$ and $3 \%$, the highest being in Bačka Palanka (2.9\%), and the lowest in Odžaci (2.01\%). The other 5 municipalities (25\%) had the percentage between $1 \%$ and $2 \%$ (Srbobran 1.92\%, Kanjiža $1.71 \%$, Bač $1.60 \%$, Titel $1.46 \%$, Žabalj 1.44\%). In Banat, the highest percentage of this category (over 4\%) was recorded in 2 municipalities (12.5\%) - Pančevo (4.21\%) and Zrenjanin (4.08\%). In 2 municipalities this percentage was between $3 \%$ and $4 \%$ (Vršac 3.55\%, Kikinda 3.36\%), and in $3(18.8 \%)$ it was between $2 \%$ and $3 \%$ (Novi Kneževac 2.34\%, Kovačica $2.20 \%$, Bela Crkva 2.11\%). The other 9 municipalities (56.3\%) had the percentage of this category between $1 \%$ and $2 \%$, the highest being in the municipality of Sečanj (1.94\%), and the lowest in 
the municipalities of Žitište (1.47\%) and Opovo (1.10\%).

\section{Conclusion}

It can be concluded that despite the obvious progress in respect of the educational level of population, this level is still not satisfactory. This is particularly true of smaller municipalities where there are no big cities, and which are far from major road links, and without any profitable industries. The situation is especially alarming in the borderland region of Banat, but also in smaller villages distant from municipality centers. The situation would certainly be more satisfactory had more attention been paid to agriculture, i.e. its more adequate treatment in the total of the economy of Vojvodina, but that of Serbia and Yugoslavia as well. Had the total economy (production and manufacturing industry), especially that of agriculture as the most important branch in Vojvodina, developed in the right direction, the intensity of the "brain drain" process, i.e. the emigration of university educated experts, would certainly have been lower. At the same time, a satisfactory development of any area, region, municipality, town or city is inconceivable without appropriately educated experts.

However, apart from the number of university educated experts it is equally important to pay attention to their structure and continuous specialization, as this is an imperative dictated by the leading world developmental trends. The great many achievements of our experts both at home and abroad prove that we are capable of keeping pace with the main world developmental trends. Together with university educated experts great care should be taken of high school education as well, as this represents the most common basis of concrete executive and developmental tasks. In addition, it is from this group

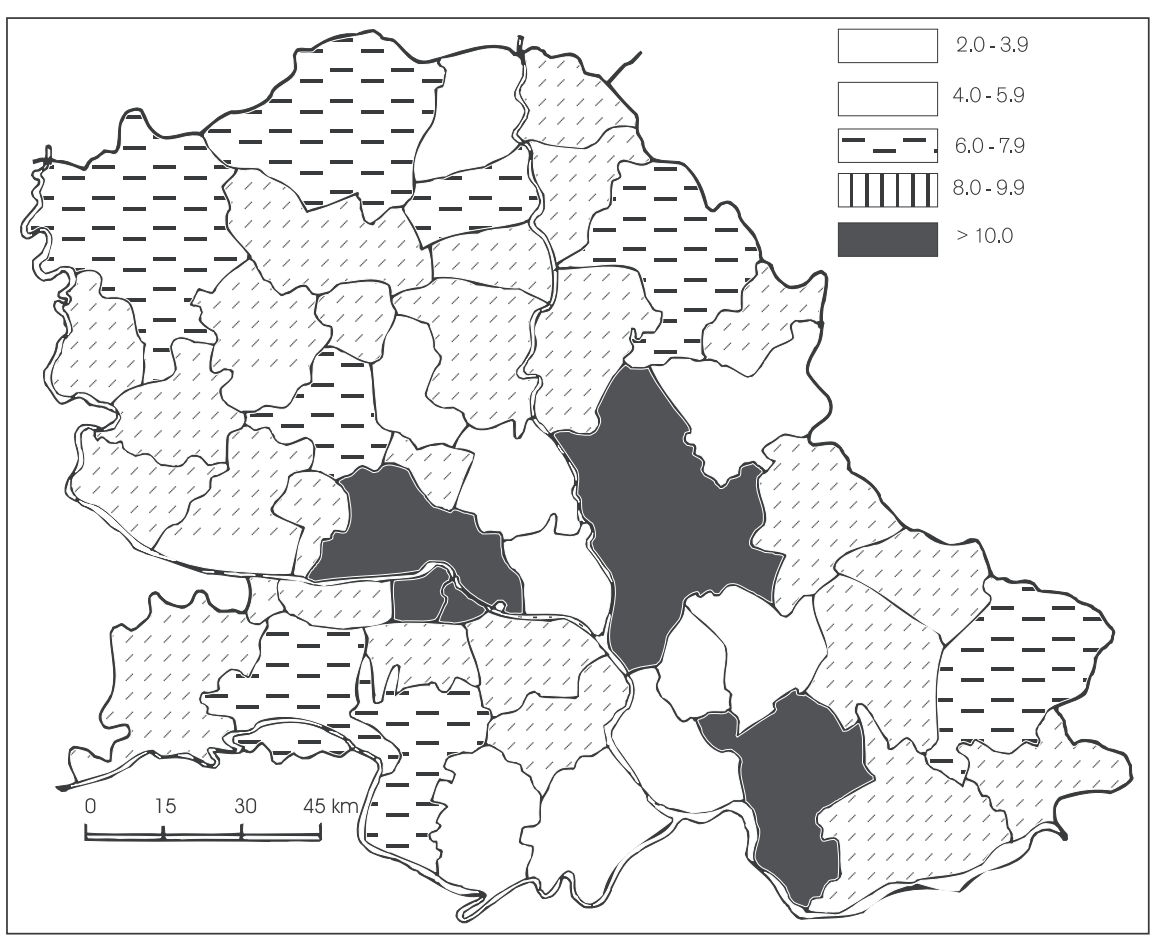

Figure 5. The percentage of population with college and university education in the municipalities of Vojvodina in 1991

of population that the university educated experts come, either by immediately continuing their education or by later additional education.

The intensive mechanization in agriculture has made a number of workers redundant, who therefore had to seek employment in urban centers. However, even the simplest jobs in cities required at least primary school education. This is why more and more people went to school thus decreasing the number of the illiterate. Besides, the law became more strict in the sense that a greater number of children had to take compulsory primary education. In addition, the number of immigrants to Vojvodina decreased significantly (until the breakout of the war in the former SFR Yugoslavia). All these factors, together with the factor of mortality, contributed to the decrease in the number of the illiterate.
The above analysis of the educational structure in Vojvodina can yield numerous results. One of the most important is that attention should be paid to coordinating the education of the total population and the development of the region, municipalities and villages. Even a most superficial analysis reveals that certain municipalities have a less developed educational structure, as well as backward or stagnating economies (Žabalj, Titel, Bač, Kanjiža, Srbobran, Odžaci, Mali Iđoš, Irig, Beočin, Pećinci, Opovo, Žitište, Plandište, Alibunar, Nova Crnja, Kovačica etc.). But it also points to those municipalities which successfully improved their status within Vojvodina in the second half of the $20^{\text {th }}$ century (Novi Kneževac, Kovin, Pančevo, Inđija, Stara Pazova, Temerin, Apatin, Bačka Palanka, Kula, Vrbas etc.). 